\title{
Civil Society, Crisis, and Change: Towards a Theoretical Framework
}

\author{
LORENZO FIORAMONTI* \& EKKEHARD THÜMLER** \\ * Department of Political Sciences, Centre for the Study of Governance Innovation, University of Pretoria, \\ South Africa; **Centre for Social Investment, Heidelberg University, Germany
}

\begin{abstract}
This concluding essay frames the actual and potential role of civil society actors in terms of institutional theory, complemented by Gramscian thought. Global finance is conceived as an institutionalized field in need of structural change triggered by institutional entrepreneurs. Reviewing the nature of problems, it becomes clear that only a wide-if probably quite loosecoalition of different actors will effect the necessary profound change. However, no such coalition is in view today. Issues related to power, wealth, and ideology are put forward as a possible explanation. We then explore the relevance of Gramsci's theory of the 'modern prince'as a challenger of 'cultural hegemony' for a response to these problems. We suppose that civil society actors have a fair chance to accomplish societal reconstruction, provided that they step up the effort in a more coordinated way and take into account the inevitable conflict it will generate.
\end{abstract}

KEY Words: Economic crisis, civil society, institutional theory, institutional entrepreneurship, cultural hegemony

Our own research on civil society's response to the financial crisis originated as an attempt to take stock of, and understand, the behaviour of philanthropic foundations. We discussed our empirical findings in terms of institutional theory and found that this approach provides us with considerable explanatory leverage and equips us with the vocabularies necessary to structure the phenomena in question. The same, we argue, holds true for the following analysis of civil society activism at large, if admittedly conducted somewhat tentatively and in very broad strokes. At the same time, some persistent weaknesses of institutional thinking, namely those related to power issues, come in view. In this respect, we agree that the present discussion provides an important opportunity for social theorists not only to make sense of the phenomena we observe, but also to develop and refine the conceptual and theoretical tools we need to deal with them (Munir, 2011).

Correspondence Address: Ekkehard Thümler, Centre for Social Investment, Heidelberg University, Adenauerplatz 1, 69115 Heidelberg, Germany. Email: ekkehard.thuemler@csi.uni-heidelberg.de 
In contrast to a more colloquial understanding of 'institutions' as familiar and often highly respected organizations or practices, the term in its more technical sense refers to those patterns and structures, rules, and procedures that guide conduct by providing scripts of action and defining expectations of 'proper' behaviour, thus providing stability and predictability of social life (Campbell, 2004; Scott, 2008, pp. 48-49; Walgenbach \& Meyer, 2008, pp. 55-63). Generally speaking, institutions are highly resistant to change as they are deeply anchored in social practice. As an unquestioned reality of social life, they may even acquire an aura of inevitability. At the same time, the development of new institutions or processes of institutional change is political in nature and can be conceived as 'settlements born from struggle and bargaining. They reflect the resources and power of those who made them and, in turn, affect the distribution of resources and power in society' (Campbell, 2004, p. 1).

We interpret the task civil society faces in reining in global finance in terms of institutional change. In our understanding, global finance constitutes an institutional field made up of organizational actors, their networks, and distinctive distributions of material resources (Rao, Morrill, \& Zald, 2000, p. 251). Rather than spinning in an institutional void or operating in a detached digital parallel world (as is often portrayed), the shape and behaviour of global finance actually rests on strong institutionalized foundations that have evolved in the last decades and cannot easily be dismantled.

Obviously, such a description lends itself to a certain degree of ambivalence. On the one hand, the financial industry has been highly successful at shaping the field to its own advantage, for instance, by harnessing the discourse of neoliberal deregulation largely endorsed by society as the sole proper governance approach. On the other hand, the sector remains essentially dependent on conditions and rules that it cannot produce on its own. For example, Sassen (2005) claims that 'in order to function these markets require specific types of guarantees of contract and protections, and specific types of deregulation of existing frameworks' (p. 31). She infers that, regardless of the 'raw power' of financial actors, this dependence on regulation provides a potential point of leverage for change, although 'the manner of this participation may well be quite different from long-established forms' (Sassen, 2005, p. 33).

Assuming that change is possible, the question is how it may come about. Scholars in the institutional tradition distinguish between two different modes of transformation, namely evolutionary processes (usually triggered by endogenous factors) versus revolutionary courses of events (typically caused by exogenous shocks). Proponents of the former argue that processes of change usually occur in a stepwise fashion, accumulating small patches over long periods of time. Scholars in this tradition also have maintained that, more often than not, path dependencies and gradualism characterize episodes that may look revolutionary at first glance (e.g. Campbell, 2004, p. 33).

The opposite position conceives of institutional change as 'punctuated equilibrium', that is, as the result of disruptive external events that break up institutional inertia, resulting in relatively quick and far-reaching change. The position thus highlights the significance of crises and ruptures in societal routines as an opportunity to radically alter the future course of events. An important role in breaking inertia is played by institutional entrepreneurs-usually newcomers to the field, who are better suited to question common routines than the representatives of the orthodoxy. The resulting struggles may or may not result in the end of an equilibrium period and the establishment of a new paradigm (Gersick, 1991; Kuhn, 1970; Romanelli \& Tushman, 1994). 
Which model is best suited to predict the future of civil society engagement with financial markets? Looking at the current global crisis, it seems fair to conclude that organic, evolutionary processes as discussed by the proponents of the reform-oriented 'governance paradigm' have not led to meaningful change in the last decades, and, in all probability, will not do so in the near future. At the same time, it seems equally improbable that the financial crisis can yet be regarded as an instance of punctuated equilibrium in the making. Taking into account the time it took for neoliberal thinking to rise, a similarly broad cultural and political counter movement seems to be needed. Putting our diagnosis in somewhat metaphorical terms, we assume that it is likely that even the severe crisis we observe today will not cause quick and deep change in the field structures of global finance but rather a comparatively small, but potentially contagious, irritation of a very broad and sluggish path. At best, these turbulences might have the potential to slightly begin to alter the direction of the mainstream of political economy, with a significant effect, that is, a considerable divergence from the direction of today's path, to be expected only in the long run.

As the present financial and economic regime faces a fundamental loss in credibility and legitimacy, actors in civil society, politics, economy, and academia might be increasingly drawn towards the exploration of alternatives. Whether these developments do take place, or not, depends on the strength and inertia of existing structures on the one hand and the level of mobilization triggered by the crisis on the other. In this respect, what civil society should realistically aim for might better be conceived as a type of 'punctuated evolution' (Campbell, 2004) in order to designate a situation in which fierce external shocks do not result in immediate revolutionary change, but rather in a viral spread of discontent, that might ultimately lead to far-reaching consequences in the body of global finance.

Who are the actors that might play a decisive role in advancing developments along these lines? The concept of 'institutional entrepreneurship' is supposed to explain how embedded actors may effect institutional change. Institutional entrepreneurs mobilize resources of different kinds, develop and communicate coherent rationales, and bring about new configurations of stakeholders, thus enabling collective action with the intention to generate institutional change (DiMaggio, 1988; Hardy \& Maguire, 2008). As the contributions to this collection show, efforts to promote change do often stem from civil society forces that are not part of the centre of society like individual philanthropists or private foundations, but often from more isolated actors playing at the periphery (on the distinction between centre and periphery of society, see Shils, 1961), often against all odds and with limited resources. These are small think tanks with ambitious advocacy plans, social movements capable of condensing the popular dissatisfaction with the status quo and grassroots networks of people who experiment with change on a daily basis by changing habits, building community resilience and, in some cases, resorting to civil disobedience.

At the same time, institutional theory reminds us of the relevance of internal sources of change. A particularly important-if certainly not very proactive-role might be played by the business associations of the finance industry itself. Building on DiMaggio and Powell (1991), Scott (2008) maintains that institutions rest on regulative, normative, and cultural-cognitive foundations. Civil society actors who lobby policy-makers to implement a tighter legal regulation in particular and more effective modes of governance in general aim mostly at enhancing regulative controls. Those who work towards a change in widely shared assumptions about what constitutes reasonable economic behaviour, thus 
attempting to change the 'prevailing ideologies regarding preferred political or economic systems' (Scott, 2008, p. 58), aim at achieving change via cultural-cognitive modes of control. The normative sources of organizational legitimacy are fed by perceptions of the appropriateness of action that is often secured through professional standard-setting, e.g. by means of certification and accreditation procedures. In these respects, business associations of global finance might play an important role as arbiters of rational professional action (cf. Greenwood, Hinings, \& Suddaby, 2002).

At first glance, this assumption might seem far-fetched, given that these organizations first and foremost reflect the interests of their members. But interests are not as homogenous as we tend to think. For instance, many employees of the financial industry, like private bankers, might have an intrinsic interest in regaining and retaining the trust of their clients. Moreover, interests are not simply given, exogenous to societal debates. If civil society is able to successfully promote a counter narrative and redefine the principles and values animating the market, then it is possible that the interests of business actors may also change (see, e.g. Swedberg, 2005 on the social construction of economic interests). Hence, if the cultural-cognitive climate changes in society at large, then business associations might eventually play an important role as transmission belts of reform for financial markets. Note that these more theoretical considerations are well in accord with Scholte's diagnosis (in this collection) of civil society's 'blind spot for private-sector regimes' and the corresponding need to pay more attention to these important yet rather opaque elements of the governance infrastructure of global finance. The same holds true for scholars of civil society organizations in the field of global finance: It would definitively be worthwhile to learn more about the landscape and networks made up of these organizations as well as the discussions and developments inside of them.

While we identified possible patterns of change as well as a number of potential candidates to exercise institutional entrepreneurship in the field of global finance, the contributions to this collection also point to major challenges for civil society activism. The decisive question is: Will the engagement of civil society in matters of global finance suffice both in qualitative and quantitative terms? After all, financial crises have bubbled up repeatedly in the last decades (see Scholte, in this collection). Yet they have attracted comparatively little civil society attention and, after minor adjustments, society has gone back to business-as-usual, waiting for the next crisis to burst. In this regard, it may not come as a surprise that two of the most prominent responses to the crisis have not been initiated by civil society but by political actors (e.g. Finance Watch) and by exponents of financial markets (the Institute for New Economic Thinking). Moreover, existing activities seem to be shattered and dispersed and the approaches, philosophies, and values espoused by these actors are often at odds with one another other. Some examples of 'de-growth', for instance, prefer working under the radar screen, avoiding taking specific political positions and even refraining from embarking on advocacy campaigns. For others, within the same strand, the rejection of political authority is, by contrast, a fundamental component of their civic action. While Finance Watch uses various channels and expertise to rein in the influence of finance and bring important issues to the attention of the broader public, it nevertheless does not refuse to engage economic powers and sees political institutions as clear counterparts to work with (rather than necessarily working against). Much to the contrary, Occupy Wall Street exemplifies a form of protest that aims to re-found democracy from the bottom up, thus rejecting the legitimacy of current power structures. 
A number of explanations for the weakness of civil society vis-à-vis the financial industry have yet been put forward and they all deserve to be discussed in their own right (Fioramonti \& Thümler, 2011; Scholte, in this collection). At this point, we will have a closer look at the role of power, assuming that an important part of the problem is due to the fact that the present financial system is not the contingent result of impersonal institutional forces or societal myths, but a consequence of the interests of wealthy and powerful social elites, 'the 1\%', as Occupy would put it, combined with a strong supportive ideology. We hypothesize that both factors contribute to the impression of an insurmountable strength of the present economic and financial regime, making it difficult for civil society actors (and, in fact, for society at large) to become aware of the ways in which one's own interests are impaired by seemingly far away markets and to conceive of options for meaningful opposition.

However, in this regard, institutional theory lacks analytical strength as it focuses mostly on structural sources of power, that is, on the restraining force institutions exert on individual or organized action to the neglect of the more interest-driven power of single actors (Clegg, 2010; Munir, 2011; Perrow, 1986). For instance, Perrow (1986) diagnoses

the failure to see society as adaptive to organizations. A view that organizations are protean in their ability to shape society would direct us to the study of the powerful organizations [...] The environment of most powerful organizations is well controlled by them. (pp. 173-174)

In a similar vein, Levy and Scully (2007) diagnose that '[w] hat is lacking is a theory of how institutional entrepreneurs can overcome structural power by outmanoeuvring field dominants' (p. 976).

They suggest that a promising way forward might be found in the fusion of institutional theory and Gramscian thought on cultural hegemony and the 'modern prince' as the driving force behind societal change, if purged of its thrust on class conflict (Levy \& Scully, 2007; for a related discussion on the role of global civil society in neo-Gramscian terms, see Katz, 2006). According to Gramsci, the ruling class in modern societies cannot reign by means of the satisfaction of material needs and/or coercion alone. The societal distribution of power and resources rests on 'cultural hegemony', that is, on the prevailing Weltanschauung that protects the interests of dominant social elites. In other words, the concept refers to power that is exercised largely in the shape of 'domination by consent', which, in turn, is made possible under the condition that the values and interests of the ruling class are successfully represented as those of society as a whole. Hegemony is won and secured by an alliance of diverse societal groups called the 'historical bloc' which succeeds in generating an 'alignment' of material, organizational, and discursive forces to its own advantage (Levy \& Scully, 2007, pp. 976-977).

How is resistance against hegemonic structures possible? Gramsci does not conceive of hegemony as a seamless wall of power but as an instance of negotiated order and historical contingency. Thus, leeway for counter-hegemonic action opens up that can be exploited systematically by the subject of societal change, the 'modern prince'-in Levy and Scully's reading the Gramscian equivalent of institutional entrepreneurs (Levy \& Scully, 2007, pp. 980-981). The modern prince is a 'collective agent' analysing the situation and its opportunity structures, creating and shaping effective organizations and 
coalitions and strategizing to achieve long-term goals in cooperative ways in order to change the power structures in a field (Levy \& Scully, 2007, p. 978). To be sure, while the term 'modern prince' (just like the concept 'institutional entrepreneur') evokes pictures of heroic individual agency, Gramsci (1971) asserts that the 'modern prince, the myth-prince, cannot be a real person, a concrete individual. It can only be an organism, a complex element of society in which a collective will [...] begins to take concrete form' (p. 129) in order to act 'on a dispersed and shattered people to arouse and organize its collective will' (Gramsci, 1971, p. 126).

We see a number of analytical advantages of this approach. To begin with the last aspect we mentioned, a major problem in civil society activation seems to be the fact that too few citizens seem to give priority to the issue of global finance. As Kern and Nam point out in their essay, the 'victims of a conflict or crisis are often unaware of their specific interests [... ] This scenario stayed true during the global financial crisis: Actors must first make sense of their situation before they can define collective interests and goals'. Taking these insights seriously and linking them to Gramscian theory, we infer that a major task for civil society actors will be to effect a sufficient level of societal 'arousal', that is, to work towards the establishment of a shared perception of the financial system as a major societal problem-keeping in mind that the very process of social problem definition is, at the same time, a profoundly political act (Blumer, 1971; Merton, 1976).

Second, what used to be a predominantly structural, overwhelmingly compact and seemingly a-personal, that is, basically untouchable, institutional power structure now comes in view as the historical, negotiated, and thus contingent, product of dominant social forces. Moreover, as the rather narrow focus of many of the case studies discussed in institutional theory (including, ironically, the study by Levy and Scully itself) widens, new perspectives on a much broader context of political economy and culture, where much more fundamental issues are at stake, open up (if, admittedly, not nearly the issues Gramsci himself would have envisaged). This aspect fits well to the contributions in this collection, most of which put emphasis on the entanglement of issues of global finance with wider and more fundamental problems, like a loss of democratic, ecologic, and humanist values.

At the same time, the options for counter-hegemonic civil society actors become more clear cut. First of all, a thorough analysis is needed to better understand the problematic situation, determine weaknesses in the positions of the incumbents of power and identify windows of opportunity. Compare these demands with Scholte's (in this collection) account of the rather limited capacities of civil society actors to develop a basic understanding of the architecture and operations of finance and the nature of governance mechanisms. Second, emphasis is put on the need to form coalitions that might ultimately take the shape of a 'historical bloc'. This is definitively not a matter of networking between NGOs alone, but requires the systematic inclusion of other powerful and influential actors of society (and the accompanying need to compromise). For instance, as part of the attempt to gain ideological sovereignty, Gramsci (1971) assigns an important role to 'organic intellectuals' that are instrumental in the mission to 'assimilate and conquer' the 'traditional intellectuals' (p. 10), in framing the problem-state in ways that are capable of winning the majority of the population, and in developing positive visions of the suggested future goal-state (note that Desai \& Said (2001) include public intellectuals and the media in their discussion of relevant forces in civil society). As many of the contributors to this collection notice, civil society is still far from reaching an adequate level of cooperation, let alone the capacity to form a 'historical bloc'. However, the considerable 
societal applause for the values and the critique put forward by the Occupy movement might indicate that options for an alignment of forces within a broad societal coalition are not so bad after all (see the essay by Kern and Nam, in this collection).

Moreover, focus is put on civil society as a dialectical place that contains forces of hegemony as well as counter-hegemony and distinctions between both are not necessarily clear cut. For instance, Desai and Said (2001) introduce the category of 'supporters' in their taxonomy of civil society actors in the field of global finance. Katz (2006) claims that civil society activists need to critically analyse the extent to which they, themselves, reproduce societal hierarchies and inequalities by excluding subaltern groups, namely, exponents of the global south, thus reproducing hegemony rather than challenging it (Katz, 2006, p. 335 and passim) and weakening their own efforts.

Finally, Levy and Scully (2007) repeatedly emphasize the need for counter-hegemonic actors to engage in strategic action, an approach they label the 'strategic face of power' (pp. 982-984). This refers not only to the capability of developing the necessary longterm orientation (and certainly not to spelling out a sophisticated plan of action), but also to the ability to quickly and flexibly operate in contested fields in order to identify and make use of existing or emerging windows of opportunity and thus to 'outmanoeuvre' larger and possibly more inertial incumbents of power. They thus suggest a remarkable combination of persistent long-term orientation on the one hand and emphasis on the capability for dynamic reaction to (or provocation of) new opportunities. This approach might in fact better be labelled 'strategic-organic', in order to accentuate the seemingly contradictory nature of necessary capabilities.

Summing our findings up, the potential success of civil society's engagement depends on a sufficient level of problem-work, mobilization and cooperation, the willingness to learn much more about the nature of the problem and possible ways to tackle it, the acceptance of the political nature of the issues that are at stake, and the capability to invent innovative models of opposition and of potential future goal-states in order not only to influence more technical governance structures but to regain cultural hegemony. The complexity and the size of the challenge are obvious, and to some observers, the powers of finance might seem to be overly strong and the task civil society actors face to be too large.

However, we think that the contributions in this collection and a view towards prior processes of transformation warrant both discarding the 'there is no alternative' (TINA) narrative as well as the avoidance of cynicism and resignation. Recall the major processes of change that have occurred in the last two decades more or less unexpectedly. The lesson of the transformation process in Eastern Europe and the so-called Arab Spring might tell us that the future is open. If civil society has repeatedly played a major role in overcoming seemingly overwhelmingly strong power structures, why should it be impossible to redirect the path of political economy? Of course, the pace of change may be slow and, as we know, relapses are always lurking behind the surface of progressive reforms. But the very notion of civil society as an arena in which hegemonic as well as counter-hegemonic discourses are constantly produced and reproduced is the best antidote against unilateralism, technocracy, and unidimensional ideologies. In this regard, it may very well be that some of the pioneering forms of contestation we observe today (some of which are still in the making) will ultimately lead to concrete and meaningful change. The current crisis, in this regard, may turn out to be a window of opportunity for the creative reconstruction of our societies. 


\section{References}

Blumer, H. (1971) Social problems as collective behaviour, Social Problems, 18(3), pp. 298-306.

Campbell, J. L. (2004) Institutional Change and Globalization (Princeton, NJ and Oxford: Princeton University Press).

Clegg, S. (2010) The state, power, and agency: Missing in action in institutional theory? Journal of Management Inquiry, 19(1), pp. 4-13.

Desai, M. \& Said, Y. (2001) The new anti-capitalist movement: Money and global civil society, in: H. K. Anheier, M. Glasius \& M. Kaldor (Eds) Global Civil Society 2001, pp. 51-78 (Oxford: Oxford University Press).

DiMaggio, P. J. (1988) Interest and agency in institutional theory, in: L. G. Zucker (Ed.) Institutional Patterns and Organizations. Culture and Environment, pp. 3-21 (Cambridge, MA: Ballinger).

DiMaggio, P. J. \& Powell, W. W. (1991) The iron cage revisited: Institutional isomorphism and collective rationality in organizational fields, in: W. W. Powell \& P. J. DiMaggio (Eds) The New Institutionalism in Organizational Analysis, pp. 63-82 (Chicago and London: The University of Chicago Press).

Fioramonti, L. \& Thümler, E. (2011) The financial crisis and the non-profit sector: Can philanthropic foundations support the creation of a civic watchdog of international finance? The International Journal of Not-ForProfit Law, 13(3), pp. 33-42.

Gersick, C. J. G. (1991) Revolutionary change theories: A multilevel exploration of the punctuated equilibrium paradigm, The Academy of Management Review, 16(1), pp. 10-36.

Gramsci, A. (1971) Selections from the Prison Notebooks of Antonio Gramsci (New York: International Publishers).

Greenwood, R., Hinings, C. R. \& Suddaby, R. (2002) Theorizing change: The role of professional associations in the transformation of institutionalized fields, Academy of Management Journal, 45(1), pp. 58-80.

Hardy, C. \& Maguire, S. (2008) Institutional entrepreneurship, in: R. Greenwood, C. Oliver, R. Suddaby \& K. Sahlin-Andersson (Eds) The Sage Handbook of Organizational Institutionalism, pp. 198-218 (London: Sage).

Katz, H. (2006) Gramsci, hegemony, and global civil society networks, Voluntas, 17, pp. 333-348.

Kuhn, T. S. (1970) The Structure of Scientific Revolutions, 2nd ed. (Chicago: University of Chicago Press).

Levy, D. \& Scully, M. (2007) The institutional entrepreneur as modern prince: The strategic face of power in contested fields, Organization Studies, 28(7), pp. 971-991.

Merton, R. K. (1976) Introduction: The sociology of social problems, in: R. K. Merton \& R. Nisbet (Eds) Contemporary Social Problems, 4th edn, pp. 3-43 (New York: Harcourt Brace Jovanovich).

Munir, K. A. (2011) Financial crisis 2008-2009: What does the silence of institutional theorists tell us? Journal of Management Inquiry, 20(2), pp. 114-117.

Perrow, C. (1986) Complex Organizations. A Critical Essay (New York: McGrawHill).

Rao, H., Morrill, C. \& Zald, M. N. (2000) Power plays: How social movements and collective action create new organizational forms, Research in Organizational Behaviour, 22, pp. 237-281.

Romanelli, E. \& Tushman, M. (1994) Organizational transformation as punctuated equilibrium: An empirical test, Academy of Management Journal, 37(5), pp. 1141-1166.

Sassen, S. (2005) The embeddedness of electronic markets: The case of global capital markets, in: K. K. Cetina \& A. Preda (Eds) The Sociology of Financial Markets, pp. 17-37 (Oxford: Oxford University Press).

Scott, W. R. (2008) Institutions and Organizations. Ideas and Interests, 3th edn (Thousand Oaks, CA: Sage).

Shils, E. (1961) Centre and periphery, in: E. Shils (Ed) The Logic of Personal Knowledge: Essays Presented to Michael Polanyi, pp. 117-130 (London: Routledge \& Kegan Paul).

Swedberg, R. (2005) Conflicts of interests in the US brokerage industry, in: K. K. Cetina \& A. Preda (Eds) The Sociology of Financial Markets, pp. 187-203 (Oxford: Oxford University Press).

Walgenbach, P. \& Meyer, R. (2008) Neoinstitutionalistische Organisationstheorie (Stuttgart: Kohlhammer). 